\title{
The potential economic impact of restricted access to angiotensin-receptor blockers
}

\author{
Jason R. Guertin MSc, Cynthia A. Jackevicius PharmD MSc, Jafna L. Cox MD, Karin Humphries DSc, \\ Louise Pilote MD PhD, Derek Y. So MD, Jack V. Tu MD PhD, Harindra Wijeysundera MD, \\ Stéphane Rinfret MD SM; for the Canadian Cardiovascular Outcomes Research Team
}

Competing interests: See end of article for competing interests.

This article has been peer reviewed.

Correspondence to: Dr. Stéphane Rinfret, stephane.rinfret@criucpq .ulaval.ca

CMAJ 2011. DOI:10.1503 /cmaj.100787

\begin{abstract}
Background: The use of angiotensin-receptor blockers increased by more than $4000 \%$ in Canada from 1996 to 2006. The benefit of these medications over angiotensin-convertingenzyme ( $A C E)$ inhibitors has not been proven aside from a reduction in dry cough. We estimated the potential cost savings that might have been achieved had access to angiotensinreceptor blockers been restricted.
\end{abstract}

Methods: We performed a cost-minimization analysis with a decision-tree model using a societal perspective over a one-year period. Sources of data for model parameters included IMS Health Canada data collected from onethird of all retail pharmacies for the cost and use of angiotensin-receptor blockers and ACE inhibitors in each province, as well as published studies for administrative costs and incidence of dry cough. We used Monte Carlo simulations with 10000 iterations to test the impact of several model parameters (e.g., drug prices, administrative costs and the incidence of dry cough). All data are in 2006 Canadian dollars.

Results: A policy that would have restricted access to angiotensin-receptor blockers might have saved more than $\$ 77$ million in Canada in 2006. The simulations yielded similar savings for the year (mean $\$ 58.3$ million, 95\% confidence interval $\$ 29.3$ million to $\$ 90.8$ million). Every simulation showed a cost savings.

Interpretation: Had access to angiotensinreceptor blockers been restricted, the potential cost savings to the Canadian health care system might have been more than $\$ 77$ million in 2006, likely without any adverse effect on cardiovascular health.

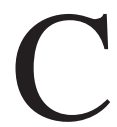
osts of cardiovascular drugs in Canada increased by more than $200 \%$ from 1996 to 2006. The use of angiotensin-receptor blockers grew at an especially high rate, rising by more than $4000 \%$ during that period. ${ }^{1}$ Such an increase in the use of these agents is not strongly supported by evidence. ${ }^{1}$ Although angiotensinreceptor blockers were effective in reducing mortality and morbidity associated with hypertension in one large trial, patients in the control group were not given an angiotensin-converting-enzyme (ACE) inhibitor. ${ }^{2}$ Instead, they received atenolol, a $\beta$-blocker, a drug class whose use is increasingly being questioned in the management of high blood pressure uncomplicated by prior myocardial infarction, heart failure or tachyarrhythmia. ${ }^{3,4}$ Although angiotensin-receptor blockers are not associated with dry cough, a side effect reported by $5 \%-35 \%$ of patients taking ACE inhibitors, ${ }^{5}$ this side effect is benign and fully reversible once the drug is stopped. Meta-analyses that included several randomized trials failed to show superiority of angiotensin-receptor blockers over ACE inhibitors for the treatment of hypertension, ${ }^{6}$ heart failure ${ }^{7}$ or the secondary prevention of coronary artery disease. ${ }^{8}$

Innovative policies are needed to offset the ever-increasing costs of cardiovascular drugs in Canada. Currently, British Columbia is the only province that restricts access to angiotensinreceptor blockers. Given that these agents can safely be substituted by ACE inhibitors and still yield similar clinical outcomes,${ }^{6-8}$ restricting their access is expected to lead to cost savings without adversely affecting patient heath. We estimated the potential cost savings that might have been achieved had access to angiotensin-receptor blockers been restricted in Canada in 2006.

\section{Methods}

\section{Study design}

We conducted a cost-minimization economic analysis using a decision-tree model with province-level data on drug costs obtained from IMS Health Canada's Canadian CompuScript Audit Database. ${ }^{1,9}$ We built the model to perform our base-case analysis and sensitivity analyses over a 
one-year period from a societal perspective (Figure 1). Using the model, we compared direct health care costs in 2006 associated with two scenarios. The first scenario reflected the status quo of no restriction on the use of angiotensin-receptor blockers across Canada except in British Columbia. Actual 2006 data on costs were used.

The second scenario tested the economic outcomes had a policy restricting the use of angiotensin-receptor blockers been implemented on Jan. 1, 2006. We assumed that patients would receive treatment for one year. Under this policy, those already taking an angiotensin-receptor blocker or an ACE inhibitor would continue taking their existing therapy for the duration of the year. New patients considered for angiotensinmodifying treatment would be prescribed an ACE inhibitor first. We assumed that constraints on the use of angiotensin-receptor blockers would be more acceptable if the initially prescribed ACE inhibitor was not one that required multiple doses per day (e.g., captopril and enalapril). Patients already receiving these ACE inhibitors, however, would not be switched to another regimen. New patients prescribed any of the other ACE inhibitors would be switched to an angiotensin-receptor blocker after the first month if dry cough developed.

In modelling the restriction-policy arm, we used province-level data on market share for the ACE inhibitors that did not require multiple daily doses. Using these data to determine the proportion of patients prescribed each ACE inhibitor as first-line treatment would tend to favour newer, and possibly more effective, agents. ${ }^{10}$ Finally, we assumed no restriction on angiotensin-receptor blockers within the class, with prescription rates of each agent based on provincial market share data for each drug in 2006.

\section{Estimation of drug use and costs}

Actual 2006 data on market shares and monthly costs for angiotensin-receptor blockers and ACE inhibitors were extracted from IMS Health Canada's Canadian CompuScript Audit Database for all provinces. This database uses audits at the retail pharmacy level to estimate the number and value of prescriptions dispensed throughout Canada. Pharmacy outlets are stratified by region, type of retailer (independent or chain store) and size. Sample stores selected for audit represent about one-third of all retail pharmacies. Data for the audit are collected monthly by electronic means. After passing through various qualitycontrol verifications, the sample data are projected to the total group of pharmacies in each region; regional totals are then summed to provide a national estimate. The data collected can be used to determine product use by drug class as well as costs of the prescriptions as dispensed (including all mark-ups and pharmacists' fees).

For our study, we included data from Jan. 1, 2005, to Dec. 31, 2006. IMS Health Canada does not measure population-wide, patient-specific data. Since we could not obtain patient-level costs, we extrapolated monthly average dispensation costs at a provincial level from the IMS Health Canada database.

Switching from an ACE inhibitor to an angiotensin-receptor blocker was assumed to be associated with additional physician consultation fees and administrative costs. We extracted physician fees from each province's physician's manual on fee schedules. ${ }^{11-18}$ Administrative fees were based on those associated with reference pricing for

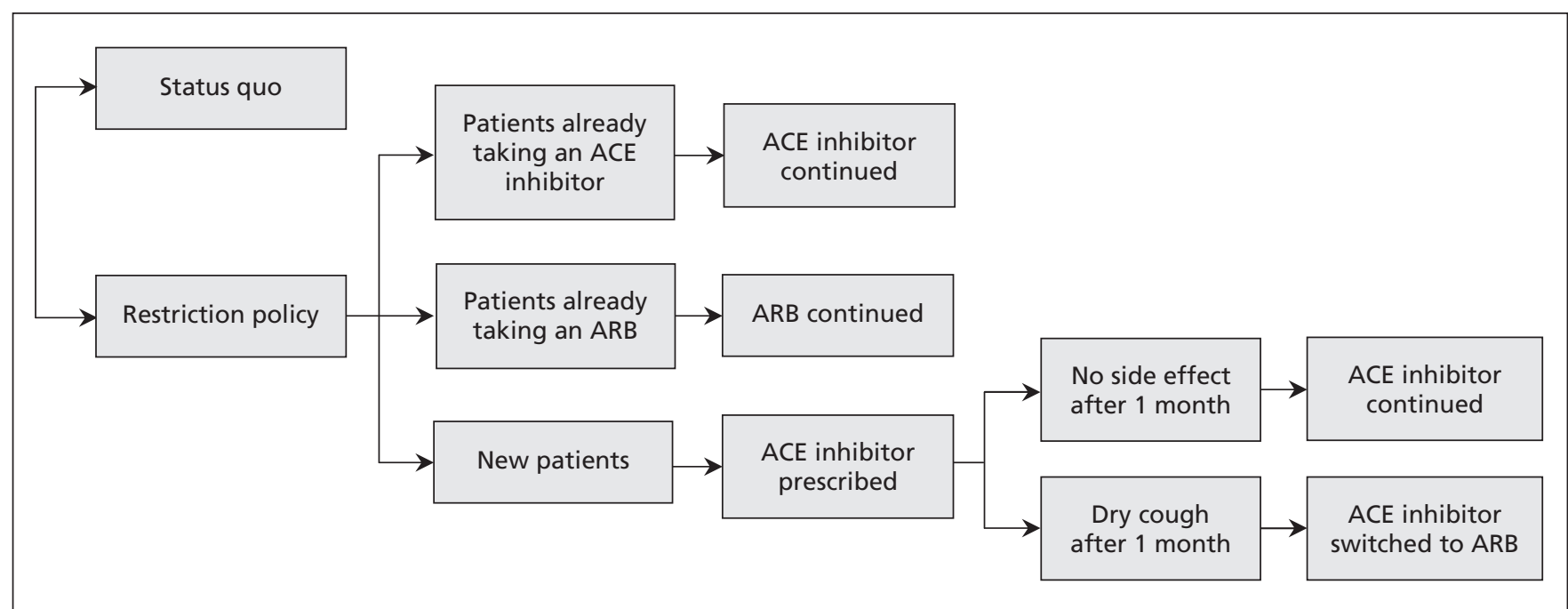

Figure 1: Decision-tree model used to compare the potential cost savings of a hypothetical policy of restricted access to angiotensin-receptor blockers and the status quo in 2006. Note: $\mathrm{ACE}=$ angiotensin-converting enzyme, ARB = angiotensin-receptor blocker. 
ACE inhibitors in British Columbia as reported by Schneeweiss and colleagues ${ }^{19}$ and were actualized to 2006 values using the Consumer Price Index for health care in 2006. To be conservative, in the Quebec model, we assumed that a pharmacist consultation fee would be required in addition to a physician fee. ${ }^{20}$

\section{Estimation of drug effectiveness and side effects}

We assumed that selected ACE inhibitors and angiotensin-receptor blockers were of equivalent effectiveness within their respective drug classes for every possible indication. ${ }^{6-8}$ This assumption was fundamental for the validity of our costminimization analysis.

From the available Canadian pharmacoepidemiologic data, we determined that $9.2 \%$ of patients prescribed an ACE inhibitor later switched to an angiotensin-receptor blocker within one year. We used this switch rate as the base-case value for the incidence of dry cough, acknowledging that switches might not be all related to this side effect of ACE inhibitor use. Angiotensin-receptor blockers were assumed to be free of side effects.

\section{Statistical analysis}

Because of variability in drug costs and utilization rates between provinces, we analyzed data for each province separately except those for Newfoundland and Labrador and for Prince
Edward Island, which we analyzed together because of how they were provided by IMS Health Canada. The savings of the restriction policy are presented in total absolute savings and relative savings. Given the short-term perspective of our analysis, no discounting was applied. To test the robustness of the base-case analysis, we used Monte Carlo simulations with 10000 iterations to estimate the impact of several model parameters. The parameters included drug costs, incidence of dry cough, new-to-existing patient ratios, number of patients affected by the restriction policy and administrative costs associated with switching from an ACE inhibitor to an angiotensin-receptor blocker.

One-way sensitivity analyses were performed to assess the impact of each model parameter on cost savings. In a final sensitivity analysis, we examined the impact of British Columbia's drug utilization ratios for new and existing patients in 2006 on each provincial model. We also applied data on British Columbia's market shares for ACE inhibitors and angiotensin-receptor blockers to each provincial model.

\section{Results}

\section{Parameter estimates}

Table 1 indicates base-case values for each parameter of interest as well as the plausible range and distribution used in the Monte Carlo simulations. Before 2006, about one-fourth of prescrip-

Table 1: Estimated values in 2006 for parameters used in the base-case model and sensitivity analyses

\begin{tabular}{|c|c|c|c|}
\hline Parameter & Base case & Variation & Distribution \\
\hline \multicolumn{4}{|l|}{ Monthly drug cost, * \$ } \\
\hline ACE inhibitors & $11190031 \S$ & $10981042-11308802 \S$ & Market shareी \\
\hline Angiotensin-receptor blockers & $16109865 \S$ & 16073 648-16 199 335§ & Market shareף \\
\hline $\begin{array}{l}\% \text { of patients already taking } \\
\text { an ACE inhibitor }\end{array}$ & $46.0 \S$ & \pm 10 & Uniform \\
\hline $\begin{array}{l}\% \text { of patients already taking an } \\
\text { angiotensin-receptor blocker }\end{array}$ & $23.2 \S$ & \pm 10 & Uniform \\
\hline $\begin{array}{l}\text { No. of patients prescribed either } \\
\text { medication in } 2006\end{array}$ & $266212 \S$ & $\pm 25 \%$ & Uniform \\
\hline Incidence of dry cough, \% & 9.2 & $5-35$ & Uniform \\
\hline Pharmacist fee†‡ & $\$ 17.59$ & NA & NA \\
\hline Physician fee $\ddagger$ & $\$ 58.94 \S$ & NA & NA \\
\hline Administrative feeł & $\$ 7.83$ & $\pm 25 \%$ & Uniform \\
\hline
\end{tabular}

Note: $\mathrm{ACE}=$ angiotensin-converting enzyme, $\mathrm{NA}=$ not applicable.

* Costs for ACE inhibitors and angiotensin-receptor blockers were derived from IMS Health Canada data and applied to the

model independently of the number of patients receiving either agent in 2006.

†The pharmacist fee was added only to the Quebec model.

$\neq$ Cost per patient who required a switch from an ACE inhibitor to an angiotensin-receptor blocker.

§Mean national values. Each provincial model used associated provincial values.

qDistribution is based on data provided by IMS Health Canada on the market share of each agent at the provincial level. The

distributions inferred the projected costs for each province had their relative market share been one of the eight observed provincial relative market shares in Canada in 2006. 
tions targeting the renin-angiotensin system were for an angiotensin-receptor blocker, and we assumed that these patients would continue to take their angiotensin-receptor blocker in 2006. We assumed that an administrative fee of $\$ 7.83$ would be applied for the evaluation of each authorization demand to switch to an angiotensin-receptor blocker as a result of dry cough from ACE inhibitor use.

\section{Actual drug use and costs}

Actual utilization rates and costs per month for each ACE inhibitor and angiotensin-receptor blocker in 2006 are shown in Table 2. The most frequently dispensed ACE inhibitors were ramipril and lisinopril. Of the angiotensin-receptor blockers, the most frequently prescribed agents were valsartan and irbesartan.

\section{Potential cost savings with restricted access}

Results of the base-case model show that a policy of restricted access to angiotensin-receptor blockers might have saved $\$ 77.1$ million overall in 2006 (Table 3); this value represents $5.6 \%$ of the total expenditures for angiotensin-receptor blockers and ACE inhibitors. Results also show potential cost savings in every province.

Table 4 shows the results of the Monte Carlo simulations for absolute and relative potential savings by province. The total absolute savings (mean $\$ 58.3$ million, 95\% confidence interval $\$ 29.3$ million to $\$ 90.8$ million) support the results of the base-case analysis. Every simulation showed a cost savings in every province.

\section{Sensitivity analyses}

In the one-way sensitivity analyses of the impact of model parameters on cost savings, only a handful of highly unlikely circumstances would have changed the direction of the results: the incidence of dry cough or the rate of switching from an ACE inhibitor to an angiotensinreceptor blocker would have to surpass $58 \%$; the percentage of patients already taking an angiotensin-receptor blocker would have to exceed $43 \%$ (reducing the proportion of new patients affected by the restriction policy to $11 \%$ ); or the administrative fees associated with switching to an angiotensin-receptor blocker would have to be more than $\$ 1738$ per prescription reviewed.

In one of the sensitivity analyses, we tested the effect of generic versions of patented drugs on potential savings. Because the most frequenly prescribed medications will be off patent by $2011,{ }^{21}$ we analyzed the effect of the restriction policy in a 2012 setting. We assumed that the price of patented drugs in 2006 that were going off patent before Jan. 1, 2012 (lisinopril, enalapril, fosinopril, eprosartan, ramipril, candesartan, irbesartan and valsartan), would be halved (based on recent legislation in Ontario limiting generic drug reimbursement to $50 \%$ of the cost of the brand name drug). All other parameters were kept at their base-case values. This analysis showed a cost saving in every province and a total potential saving across Canada of \$19.9 million $(2.3 \%$ relative savings compared to the total cost of ACE inhibitors and angiotensin-receptor blockers).

In the sensitivity analysis of the impact of British Columbia's existing-to-new patient ratios and market shares on each provincial model, the results were similar to those of the base-case analysis, with a potential savings of $\$ 85$ million.

\section{Interpretation}

Our analyses showed that, had a policy restricting access to angiotensin-receptor blockers been implemented in Canada in 2006, the cost savings that year might have been $\$ 77.1$ million, likely without any adverse effect on health outcomes. A restrictive policy is currently in place in the province of British Columbia. In one of our sensitivity analyses, in which we used the same market shares observed in British Columbia in

Table 2: Actual data on market shares and monthly utilization rates and costs for ACE inhibitors and angiotensin-receptor blockers in 2006

\begin{tabular}{|lccc|}
\hline Medication & $\begin{array}{c}\text { No. of } \\
\text { \% of national } \\
\text { market share }\end{array}$ & $\begin{array}{c}\text { Cost } \\
\text { prescriptions } \\
\text { per month }\end{array}$ & \begin{tabular}{c} 
per month, \$ \\
\hline ACE inhibitor
\end{tabular} \\
\hline Ramipril & 51.3 & 746513 & 488839477 \\
\hline Enalapril & 15.7 & 163337 & 149250024 \\
\hline Lisinopril & 9.9 & 166824 & 94627578 \\
\hline Perindopril & 7.4 & 119807 & 70433169 \\
\hline Quinapril & 7.0 & 110458 & 66967011 \\
\hline Fosinopril & 3.9 & 78762 & 37537172 \\
\hline Cilazapril & 2.4 & 44457 & 23034690 \\
\hline Trandolapril & 1.5 & 25277 & 14416529 \\
\hline Angiotensin-receptor & & & \\
blocker & & 133034 & 149222836 \\
\hline Irbesartan & 24.5 & 97636 & 147348843 \\
\hline Valsartan & 24.2 & 70965 & 116876630 \\
\hline Candesartan & 19.2 & 72734 & 116112387 \\
\hline Losartan & 19.1 & 53285 & 71741136 \\
\hline Telmisartan & 11.8 & 5950 & 7259310 \\
\hline Eprosartan & 1.2 & & \\
\hline Note: ACE = angiotensin-converting enzyme. & & & \\
\hline
\end{tabular}


2006, we found that the potential savings of $\$ 85$ million was similar to the savings projected in the base-case analysis.

Administrators of drug benefit plans need to consider carefully the restriction of specific drugs, let alone an entire class, especially in the absence of an effective alternative. In Quebec and Ontario, restricted access to clopidogrel led to underuse and increased mortality. ${ }^{22,23}$ However, in the case of angiotensin-receptor blockers, restricted access can result in substantial savings without leading to underuse or adverse clinical outcomes. In Sweden, reimbursement restrictions for angiotensin-receptor blockers were implemented in 2008. Since then, the pro-

Table 3: Potential cost savings in one year with a policy restricting access to angiotensin-receptor blockers (base-case model)

\begin{tabular}{|lcc|}
\hline Province* & $\begin{array}{c}\text { Absolute savings, } \\
\text { \$ millionst }\end{array}$ & $\begin{array}{c}\text { Relative } \\
\text { savings, \% }\end{array}$ \\
\hline Alberta & 9.5 & 6.4 \\
\hline Saskatchewan & 3.2 & 6.7 \\
\hline Manitoba & 4.5 & 8.8 \\
\hline Ontario & 32.9 & 5.4 \\
\hline Quebec & 18.3 & 4.7 \\
\hline New Brunswick & 2.5 & 5.8 \\
\hline Nova Scotia & 4.1 & 7.1 \\
\hline $\begin{array}{l}\text { Newfoundland and Labrador, } \\
\text { and Prince Edward Island }\end{array}$ & 2.1 & 5.9 \\
\hline Total & 77.1 & 5.6 \\
\hline $\begin{array}{l}\text { *British Columbia is excluded from the model because it already has a restrictive policy for } \\
\text { this drug class. } \\
\text { tAmounts are in 2006 Canadian dollars. }\end{array}$ & \\
\hline
\end{tabular}

Table 4: Potential cost savings in one year with a policy restricting access to angiotensin-receptor blockers (Monte Carlo simulations)

\begin{tabular}{|c|c|c|}
\hline Province* & $\begin{array}{l}\text { Absolute savings, } \\
\$ \text { millions }(95 \% \mathrm{Cl}) \dagger\end{array}$ & $\begin{array}{l}\text { Relative savings, } \\
\%(95 \% \mathrm{Cl})\end{array}$ \\
\hline Alberta & $7.3 \quad(4.0-11.1)$ & $4.9(2.7-7.5)$ \\
\hline Saskatchewan & $2.4(1.3-3.6)$ & $5.0(2.7-7.5)$ \\
\hline Manitoba & $3.4(2.1-4.9)$ & $6.7(4.2-9.6)$ \\
\hline Ontario & $25.4(12.8-39.4)$ & $4.2(2.1-6.4)$ \\
\hline Quebec & $12.9(5.0-21.6)$ & $3.3(1.3-5.6)$ \\
\hline New Brunswick & $2.0 \quad(1.2-3.0)$ & $4.7(2.8-7.0)$ \\
\hline Nova Scotia & $3.4 \quad(2.2-4.8)$ & $6.0(3.9-8.4)$ \\
\hline $\begin{array}{l}\text { Newfoundland and Labrador, } \\
\text { and Prince Edward Island }\end{array}$ & $1.4 \quad(0.6-2.3)$ & $3.8(1.6-6.4)$ \\
\hline Total & $58.3(29.3-90.7)$ & $4.2(2.1-6.6)$ \\
\hline \multicolumn{3}{|c|}{$\begin{array}{l}\text { Note: } \mathrm{Cl}=\text { confidence interval. } \\
\text { *British Columbia is excluded from the model because it already has a restrictive policy for } \\
\text { this drug class. } \\
\text { †Amounts are in } 2006 \text { Canadian dollars. }\end{array}$} \\
\hline
\end{tabular}

portion of the Swedish population dispensed an angiotensin-receptor blocker decreased by $24 \%$ in favour of other drugs and led to a decrease of close to $5 \%$ in total drug expenditures. ${ }^{24}$

Other simple ways to save money have been proposed, such as switching from a thiazide diuretic plus either an ACE inhibitor or an angiotensin-receptor blocker to a single combination product. Such a strategy could potentially save up to $\$ 45$ million, again without any adverse effect on cardiovascular health and likely with a favourable impact on drug adherence. ${ }^{25}$ Given a future of increasing economic uncertainty complicated by a demographic shift to an older population with a relatively shrinking tax base, measures are needed to deal with the rising health care costs. ${ }^{26}$ Policies can neither be draconian nor take a one-size-fits-all approach. Patient well-being must always come first. Cost-sharing strategies such as co-payments or caps are a less satisfactory solution to the increasing costs of cardiovascular medications, because they shift the financial burden to patients and may lead to underuse and adverse clinical outcomes. ${ }^{27}$

We believe that, where treatment choice exists, favouring the least expensive medication over others of comparable effectiveness is one way to address future economic challenges without creating social disparities.

\section{Limitations}

Our study has limitations. First, we did not assess clinical outcomes because we were unable to obtain patient-level information. The assumption of equivalent outcomes with ACE inhibitors and angiotensin-receptor blockers may not be true in Canada, although this is extremely unlikely based on the bulk of evidence. In addition, we considered that all se lected drugs were equivalent for every possible indication; however, there is still debate on the actual equivalence of these drugs.

Second, we considered only direct medical costs despite the societal perspective of our analysis. Costs not related to health care are likely negligible compared with the overall economic benefits of the policy.

Third, although side effects other than dry cough are known to be associated with ACE inhibitors, ${ }^{28}$ we limited our analysis to dry cough.

Finally, the short timeline of our base-case analysis ignores the effect of future generic and cheaper angiotensin-receptor blockers. However, as seen in our projected sensitivity analysis of the effect of brand name drugs going off patent in 2012, the policy of restricted access would still result in cost savings, although to a lesser degree (\$19.9 million v. \$77.1 million). 


\section{Conclusion}

A policy of restricted access to angiotensinreceptor blockers might have saved the Canadian health care system $\$ 77.1$ million in 2006, likely without any adverse effect on cardiovascular health. Such strategies need to be considered in order to contain the steadily increasing costs of cardiovascular care.

\section{References}

1. Jackevicius CA, Cox JL, Carreon D, et al. Long-term trends in use of and expenditures for cardiovascular medications in Canada. CMAJ 2009;181:E19-E28.

2. Dahlof B, Devereux RB, Kjeldsen SE, et al. Cardiovascular morbidity and mortality in the Losartan Intervention For Endpoint reduction in hypertension study (LIFE): a randomised trial against atenolol. Lancet 2002;359:995-1003.

3. Carlberg B, Samuelsson O, Lindholm LH. Atenolol in hypertension: Is it a wise choice? Lancet 2004;364:1684-9.

4. Kaplan NM. Beta-blockers in hypertension: adding insult to injury. J Am Coll Cardiol 2008;52:1490-1.

5. Dicpinigaitis PV. Angiotensin-converting enzyme inhibitorinduced cough: ACCP evidence-based clinical practice guidelines. Chest 2006;129(Suppl):169S-73S.

6. Matchar DB, McCrory DC, Orlando LA, et al. Systematic review: comparative effectiveness of angiotensin-converting enzyme inhibitors and angiotensin II receptor blockers for treating essential hypertension. Ann Intern Med 2008;148:16-29.

7. Lee VC, Rhew DC, Dylan M, et al. Meta-analysis: angiotensinreceptor blockers in chronic heart failure and high-risk acute myocardial infarction. Ann Intern Med 2004;141:693-704.

8. Yusuf S, Teo KK, Pogue J, et al. Telmisartan, ramipril, or both in patients at high risk for vascular events. N Engl J Med 2008; 358:1547-59.

9. Jackevicius CA, Tu JV, Ross JS, et al. Use of ezetimibe in the United States and Canada. N Engl J Med 2008;358:1819-28.

10. Pilote L, Abrahamowicz M, Rodrigues E, et al. Mortality rates in elderly patients who take different angiotensin-converting enzyme inhibitors after acute myocardial infarction: A class effect? Ann Intern Med 2004;141:102-12.

11. Manuel des médecins omnipraticiens. Quebec City (QC): Régis de l'assurance maladie du Québec; 2005. Available: www.ramq.gouv .qc.ca/fr/professionnels/manuels/100/000_complet_acte_omni.pdf (accessed 2010 Aug. 16).

12. Schedule of benefits for physician services under the Health Insurance Act. Toronto (ON): Ministry of Health and Long-Term Care; 2010. Available: www.health.gov.on.ca/english/providers /program/ohip/sob/physserv/physserv_mn.html (accessed 2010 Aug. 16).

13. Alberta Health and Wellness schedule of medical benefits. Alberta Health Care Insurance Plan: medical price list as of 01 October 2010. Edmonton (AB): Government of Alberta; 2010. Available: www.health.alberta.ca/documents/SOMB-medicalprice-list.pdf (accessed 2010 Aug. 16).

14. Saskatchewan Health payment schedule for insured services provided by a physician. In: Saskatchewan Health regional health services policy and procedure manual: payment schedule for Saskatchewan physicians. Regina (SK): Saskatchewan Health; 2008. Available: www.health.gov.sk.ca/physician-paymentschedule-october-2008 (accessed 2010 Aug. 16).

15. Manitoba physician's manual. Winnipeg (MB): Manitoba Health; 2010. Available: www.gov.mb.ca/health/documents /physmanual.pdf (accessed 2010 Aug. 16).

16. Physician's manual: medicare. Schedule of fees of the New Brunswick Medical Society, March 27, 2008. Fredericton (NB): New Brunswick Medical Society; 2008. Available: www.gnb.ca /0394/pdf-en/PhysiciansManual-e.pdf (accessed 2010 Aug. 16).

17. Physician's manual. Halifax (NS): Nova Scotia Medical Services Insurance; 2010. Available: www.gov.ns.ca/health/reports/pubs /MSI_Physicians_Manual_2010.pdf (accessed 2010 Aug. 16).

18. Payment schedule: medical care plan. St. John's (NL): Department of Health and Community Services; 2009. Available: www .health.gov.nl.ca/health/mcp/providers/full_mcp_payment_schedule .pdf (accessed 2010 Aug. 16).

19. Schneeweiss S, Dormuth C, Grootendorst P, et al. Net health plan savings from reference pricing for angiotensin-converting enzyme inhibitors in elderly British Columbia residents. Med Care 2004;42:653-60.

20. Entente entre l'Association québécoise des pharmaciens pro- priétaires et le Ministre de la Santé et Services sociaux. Québec (QC): Régie de l'assurance maladie du Québec; 2009.

21. Patent Register. Available: http://www.hc-sc.gc.ca/dhp-mps /prodpharma/patregbrev/index-eng.php (accessed 2010 Sept. 14).

22. Sheehy O, LeLorier J, Rinfret S. Restrictive access to clopidogrel and mortality following coronary stent implantation. CMAJ 2008; 178:413-20

23. Jackevicius CA, Tu JV, Demers V, et al. Cardiovascular outcomes after a change in prescription policy for clopidogrel. N Engl J Med 2008;359:1802-10.

24. Wettermark B, Godman B, Neovius M, et al. Initial effects of a reimbursement restriction to improve the cost-effectiveness of antihypertensive treatment. Health Policy 2010;94:221-9.

25. Stankus V, Hemmelgarn B, Campbell NR, et al. Reducing costs and improving hypertension management. Can J Clin Pharmacol 2009; 16:e151-5.

26. Romanow RJ. Building on values. The future of health care in Canada - final report. Ottawa (ON): Commission on the Future of Health Care in Canada; 2002. Available: http://publications.gc .ca/site/eng/237274/publication.html (accessed 2010 Dec. 17).

27. Goldman DP, Joyce GF, Zheng Y. Prescription drug cost sharing: associations with medication and medical utilization and spending and health. JAMA 2007;298:61-9.

28. Cicardi M, Zingale LC, Bergamaschini L, et al. Angioedema associated with angiotensin-converting enzyme inhibitor use: outcome after switching to a different treatment. Arch Intern Med 2004;164:910-3.

Competing interests: Jason Guertin has received consulting fees from Sanofi-Aventis. Stéphane Rinfret has received research grants and consulting fees from Pfizer Canada, Bristol-Myers Squibb and Sanofi-Aventis. Jafna Cox has received honoraria or consulting fees from Bristol-Myers Squibb, Sanofi-Aventis, Pfizer, Boehringer Ingelheim and Astra Zeneca, and research funding support from Merck and Pfizer. No competing interests declared by the other authors.

Affiliations: From the Centre de recherche du Centre hospitalier de l'Université de Montréal (Guertin), Montréal, Que.; the College of Pharmacy, Western University of Health Sciences (Jackevicius), Pomona, Calif.; the University of Toronto and the Institute for Clinical Evaluative Sciences (Jackevicius, Tu), Toronto, Ont.; the Division of Cardiology, Dalhousie University, and Capital Health (Cox), Halifax, NS; the Centre for Health Evaluation and Outcome Sciences (Humphries), Vancouver, BC; the Division of General Internal Medicine, McGill University and McGill University Health Centre (Pilote), Montréal, Que.; the University of Ottawa Heart Institute (So), Ottawa, Ont.; the Sunnybrook Health Sciences Centre (Tu, Wijeysundera), Toronto, Ont.; and Institut universitaire de cardiologie et de pneumologie de Québec and Université Laval (Rinfret), Québec, Que.

Contributors: Jason Guertin performed the statistical analyses, interpreted the results and drafted the manuscript. Cynthia Jackevicius acquired the data, assisted in the statistical analyses and revised the manuscript for important intellectual content. Jafna Cox, Karin Humphries, Derek So, Louise Pilote, Jack Tu and Harindra Wijeysundera contributed substantially to the study concept and design and the interpretation of the data, and revised the manuscript for important intellectual content. Stéphane Rinfret designed the study and revised the manuscript for important intellectual content. All of the authors approved the final version of the manuscript submitted for publication.

Funding: This study was supported by a Team Grant in Cardiovascular Outcomes Research to the Canadian Cardiovascular Outcomes Research Team from the Canadian Institutes of Health Research (CIHR). Stéphane Rinfret is a junior physician-scientist supported by the Fonds de la recherche en santé du Québec (FRSQ). Jafna Cox is the Heart and Stroke Foundation of Nova Scotia Endowed Chair in Cardiovascular Outcomes Research. Jack Tu is supported by a Canada Research Chair in Health Services Research and by a Career Investigator Award from the Heart and Stroke Foundation of Ontario. Louise Pilote is a James McGill Chair and national investigator supported by the FRSQ. Harindra Wijeysundera is supported by a research fellowship from the CIHR. 
The results and conclusions of this study are those of the authors and should not be attributed to any of the funding or sponsoring agencies. All decisions regarding the study design, publication and data analysis were made independent of the funding agencies.

Acknowledgements: The authors gratefully acknowledge IMS Health Canada, in particular the External Affairs Department, for generously providing data from the Canadian CompuScript Audit Database. They also acknowledge Daniel Carreon, BSc, for his work in data compilation.

Members of the Canadian Cardiovascular Outcomes Research Team: Dr. Jack V. Tu, Institute for Clinical Evaluative Sciences, Sunnybrook Health Sciences Centre, University of Toronto, Toronto, Ont.; Dr. William Ghali, University of Calgary, Calgary, Alta.; Dr. Louise Pilote, Division of General Internal Medicine, McGill University and McGill University Health Centre, Montréal, Que.; Dr. Jafna L. Cox, Division of Cardiology, Dalhousie University, and Capital Health, Halifax, NS; Dr. Douglas S. Lee, Institute for Clinical Evaluative Sciences, and Division of Cardiology, Toronto General Hospital, Toronto, Ont.; Ms. Karin H. Humphries, the Centre for Health Evaluation and Outcome Sciences, Vancouver, BC; Dr. David Alter, Institute for Clinical Evaluative Sciences, and Division of Cardiology, St. Michael's Hospital and the Toronto Rehabilitation Institute, Toronto, Ont.; Mr. Peter Austin, Institute for Clinical Evaluative Sciences, and Dalla Lana School of Public Health, University of Toronto, Toronto, Ont.; Dr. Mark J. Eisenberg, Divisions of Cardiology and Clinical Epidemiology, Jewish General Hospital and McGill University, Montréal, Que.; Mr. William M. Flanagan, Statistics Canada, Ottawa, Ont.; Ms. P. Diane Galbraith, Foothills Medical Centre and University of Calgary, Calgary, Alta.; Dr. Michelle M. Graham, Division of Cardiology, University of Alberta, Edmonton, Alta.; Mr. Jason R. Guertin, Centre de recherche du Centre hospitalier de l'Université de Montréal, Montréal, Que.; Dr. Ansar Hassan, Department of Cardiac Surgery, Saint John Regional Hospi- tal, Atlantic Health Sciences Corporation, Saint John, NB; Dr. Gregory M. Hirsch, Department of Surgery, Dalhousie University, Halifax, NS; Dr. Thao Huynh, Research Institute of the McGill University Health Centre, Montréal, Que.; Ms. Cynthia A. Jackevicius, College of Pharmacy, Western University of Health Sciences, Pomona, Calif., and Institute for Clinical Evaluative Sciences, Toronto, Ont.; Ms. Helen L. Johansen, Health Analysis Division, Statistics Canada, and Department of Community Medicine and Epidemiology, University of Ottawa, Ottawa, Ont.; Dr. Merril L. Knudtson, Libin Cardiovascular Institute of Alberta, Calgary, Alta.; Dr. Dennis T. Ko, Division of Cardiology, Schulich Heart Centre, Sunnybrook Health Sciences Centre and University of Toronto, and Institute for Clinical Evaluative Sciences, Toronto, Ont.; Dr. Michael P. Love, Department of Medicine, Queen Elizabeth II Health Sciences Centre and Dalhousie University, Halifax, NS; Dr. Douglas G. Manuel, Ottawa Health Research Institute, Ottawa, Ont.; Ms. Colleen M. Norris, Faculties of Nursing and Medicine, University of Alberta, Edmonton, Alta.; Dr. Wayne Putnam, Department of Family Medicine, Dalhousie University, Halifax, NS; Dr. Stéphane Rinfret, Institut universitaire de cardiologie et de pneumologie de Québec and Université Laval, Québec, Que.; Dr. Michael J. Schull, Institute for Clinical Evaluative Sciences, and Department of Medicine, University of Toronto, Toronto, Ont.; Dr. Derek Y. So, University of Ottawa Heart Institute, Ottawa, Ont.; Ms. Therese A. Stukel, Institute for Clinical Evaluative Sciences, Toronto, Ont.; Mr. Lawrence W. Svenson, Surveillance and Environmental Health, Alberta Health and Wellness, and School of Public Health, University of Alberta, Edmonton, Alta.; Dr. Christopher R. Thompson, St. Paul's Hospital and University of British Columbia, Vancouver, BC; Dr. Karen Tu, Institute for Clinical Evaluative Sciences, and Department of Family and Community Medicine, University of Toronto, Toronto, Ont.; Ms. Nancy A. Walton, Daphne Cockwell School of Nursing, and chair, Research Ethics Board, Ryerson University, Toronto, Ont.; and Dr. Harindra Wijeysundera, Sunnybrook Health Sciences Centre, Toronto, Ont. 